\title{
Economic Strategy in Kuwait and Currency Stability Factors
}

\author{
Author/ Mariam Ahmed Almutairi \\ MSc Development Economics, Department of Economics, SOAS University of \\ London, United Kingdom
}

Email: Mariammatr87@gmail.com

\begin{abstract}
:
Recently there has been an increase in interest in using a strategy for developing a strategy on which the economy is based in countries, and it has become one of the most important indicators of the development of society, and development in society is not achieved without its presence, as the world is going through our time with economic problems and crises that did not exist before. It was affordable in front of developing and backward societies that did not develop a deliberate economic strategy, but it was better with countries that are aware of this development and the importance of planning to achieve economic development in the country. Therefore, the study aimed to try to identify the economic strategy followed in the State of Kuwait, and what are the factors affecting the exchange rate and how The stability of the currency in the country, and the plans developed by the State of Kuwait by studying economic indicators and benefiting from previous studies of economic planning. The descriptive approach was used to determine the weariness of the strategy followed to raise the economic development in the country.
\end{abstract}

Keywords: Currency, Kuwait, Economic, Stability, Strategy. 


\section{Introduction:}

Achieving the stability of the economy in society is linked to the stability of the currency, and the development of a comprehensive strategy for economic development, and this is what countries seek to achieve. In economic strategies, and this the State of Kuwait sought to achieve and to set a holistic policy aimed at developing the Kuwaiti economy, and combating all pressures that could affect the national economy in the country, it is also interested in studying the factors affecting the exchange rate and achieving balance in the currency for both "supply and demand".

\subsection{Study Questions:}

The objectives of the study depend on answering a set of questions related to the subject of scientific research, and the main question of the research is "What is the economic strategy followed in the State of Kuwait, and what are the factors affecting the currency?"

Accordingly, many sub-questions must be answered to achieve the objectives of the research, which are as follows:-

1) What are the most important elements of the economic strategy in the State of Kuwait?

2) What are the general objectives that the Kuwaiti economy desires to achieve?

3) What is the policy followed in the country's labor market?

4) What are the factors affecting the exchange rate in the State of Kuwait?

5) What are the factors that determine the stability of the currency in the country?

6) What are the ways to achieve economic development?

7) What are the stages of strategic planning for economic development in the State of Kuwait? 
8) What is the role of economic diplomacy within the economic strategy program in the State of Kuwait?

\subsection{Study Aims:}

This research aims to achieve important goals in the field of scientific research represented in the following:

1) Getting to know the strategy adopted in the State of Kuwait in achieving economic development.

2) Identifying the most important factors leading to the stability of the currency in the State of Kuwait.

3) Getting acquainted with the Kuwaiti labor market policy in various sectors.

4) Identifying the most important developments and achievements made by the economy in the State of Kuwait.

5) Identifying the imbalance in the Kuwaiti economy, its most important causes, and how to address it.

6) Identifying consumer patterns in the State of Kuwait.

7) Familiarize yourself with the state's general revenues and budget.

8) Familiarize yourself with the exchange rate policies followed in the State of Kuwait.

9) Identify the role of economic development in achieving economic development in the country.

\subsection{Study Importance:}

\section{The practical importance of the research:}

The importance of this study is highlighted in a number of main points, the most important of which are the following: 
1) This topic is of contemporary importance in the field, and familiarization with the policies followed in the State of Kuwait.

2) Clarify the economic strategies followed in the country to identify the factors of development and achieve development, and to address the damages that impede development processes.

\section{- Scientific importance of the research:-}

1) Contribute to conducting research and scientific studies on the subject of the research, filling the gaps that the researchers did not reach, and adding a new scientific subject to the research topic.

2) The importance of scientific research is determined by the importance of the subject itself; as it represents an important basic knowledge base in the field of scientific research for the humanities and social sciences to obtain all the necessary information in this field.

\subsection{Research Methodology:}

After describing the research problem and trying to find a scientific analysis for the research topic; The analytical descriptive approach was chosen because it represents an effective and appropriate method for the research studies and research topic.

\subsection{Search terms:-}

\section{Strategy concept:-}

In the language:-

It is a source name, plural strategies, and means plan. Or is the plan of action.

In the Oxford Dictionary: - means planning or politicians mole.

\section{The concept of economic strategy:-}

In terms:- 
It is the plan followed to achieve an increase in production and services, through the organization of efforts and activities.

These are the planned processes of social change, to move to a better economic situation in proportion to the available economic possibilities.

Procedural definition: Comprehensive management of all economic operations to achieve the country's national interests.

The economic strategy is: - that process that aims to promote economic development that depends on the use of technical and technological means to improve the economic conditions, through the application of development plans to enhance the economy of the state and to benefit from all the economic resources and available wealth.

\section{Currency concept:}

In the language: It is a noun, collected in coins, and what is meant by it is the wages of workers.

In terms: It is the unit used in commercial transactions, which is different from one country to another.

\section{Currency stability strategy:}

It is the plan followed that the monetary authorities seek to achieve that negatively affects economic stability, which stems from price fluctuations and economic costs, and is achieved by achieving a balance between both (demand and supply).

\section{Previous Studies:}

BEUN ASEM Study: "The Economic Diversification Strategy Based on Innovation in Kuwait", Kuwait, 2015, This study aimed to identify the economic diversification policy and the economic strategy followed in the State of Kuwait, to enable the transition to a strong economy based on a successful strategy, using a sample. 
The government sector", as well as using the descriptive approach in analyzing and describing the data and indicators of the country's economic strategy.

Study "Mohammed Naji Al-Tuni:" Labor and Human Development Policies in the Arab Countries: An Analysis of the Kuwaiti Experience", 2002 AD: This study aimed to identify the nature of the economic strategy followed in the State of Kuwait, and the researcher discussed the economic policies adopted and human resource development, and reviewed the most important developments that have passed The economic development in the State of Kuwait, the development of the labor market, and he also mentioned the most important manifestations of the imbalance in economic development, and how to solve it.

The study of Muhammad Anas Abu Al-Shamat: "Trends of the Knowledge Economy in the Arab Countries", 2012 AD, this study aimed to reach the patterns of knowledge in modern economic strategies in various Arab countries, and to try to identify the extent of their impact on the economic system in the state and human life and the extent to which it is related to the progress of countries Which takes this strategic pattern in the state's economy, and the researchers tried in his study to know the most important economic problems that the Arab countries suffer from, and the role of this strategy in development processes; The researcher relied on the use of the descriptive approach in the study of the knowledge economy, and the use of the induction approach to benefit from the experiences of applying this strategy in the Arab countries.

\section{Theoretical framework:}

\section{Planning the economic strategy:-}

These are the economic activities pursued to achieve economic development and crystallize objectives towards it. It is based on several elements, including the following points:

* The strategic economic power of the state.

* Maintaining customized strategies in the markets. 
* Preserving the sources of national income, and obtaining various sources.

* Take advantage of the available resources.

* Providing various job opportunities.

* Work to raise the levels of income and production.

* Achieving consistency between different economic activities and policies.

The characteristics on which the country's economic strategy is based:

- Achieving the development goals of economic strategies.

- Achieving economic growth rates in the country.

- Attempting to solve the internal environment problems in the country.

- Integrating both the principles of subjective economics and government investigation.

- Exploiting the resources available in the country.

- The use of scientific methods in strategic planning.

The objectives of the economic strategy in the State of Kuwait:

Countries are interested in effective strategies in the field of economy to achieve the main objectives:

Work to increase national income.

- Developing the standard of living for members of the community.

Facing crises facing the weak economy of the country.

- Enhancing private investments in the resources owned by the state.

Providing all means that lead to the advancement of production in the country and the improvement of public services. 
Providing means of support for public funds, and financial reserves in the central and commercial banks.

- Studying the factors controlling the exchange rate and achieving equilibrium to obtain currency stability.

- Paying attention to commercial transactions related to exports and imports to the country.

Achieving integration in the efforts of the state's economic strategy and other strategies.

- Addressing the problems related to inflation in the country.

Reducing the spread of corruption in the administration and its impact on the state's economy.

Finding all ways to pay off any foreign debts, And work to provide aid to other countries.

- Attention to the development and application of laws that limit the presence of corruption in any sector.

\section{Monetary policies:}

Monetary policy works to raise the economic growth rates in the country; As it is done by creating the economic climate in the country, in addition to providing credit for various projects, the opinions of the schools of thought in this context varied. Classical thought may see that the rates of economic growth require increased savings in the state, to reduce consumption.

\section{Achieving price stability "currency":-}

The monetary authorities in the State of Kuwait seek to achieve currency stability, to counteract the idea of price fluctuations and economic costs. Therefore, here comes the importance of the economic strategy carried out by the state and the 
development of plans. This helped achieve economic development and achieve a balance between supply and demand.

\section{The basic elements of economic stability:-}

Interest rate stability: - raising the rates of economic performance depends on the stability of the interest rate, as fluctuations in the price lead to imbalance and difficulty in predicting the future.

\section{The stability of financial markets:-}

Avoiding financial crises that the state may go through requires the existence of a financial system that the monetary authority seeks to achieve; Because if the opposite happened, it would affect credit policy, investments, and economic growth in general.

The stability of the exchange markets: - After the developments witnessed in our world today, the exchange markets have become one of the important factors that must be studied to draw a map of the economic strategy, because monetary policy must be consistent with growth rates and ultimately lead to economic stability and currency stability.

\section{The strategic economic power of the State of Kuwait}

The strength of the state and its ability to prove its position, and to participate in providing aid to other countries is coupled with the existence of a strong strategy in the economy "economic strength", which led to achieving security within Kuwaiti society, and benefiting from the experiences of other countries when economic crises occur to them, for example, the transformation of Some countries go from weak to strong countries that no one can compete with because of the presence of economic power, so owning economic power with available resources and combining efforts with qualified cadres in this economic field is an important strategic arrangement that all countries need. 


\section{Conclusion:}

The development of any society is based on achieving economic development and developing a strategy; Through the analysis of the economic environment, and the global crises that the global economy is going through, it was found that there are fierce conflicts to achieve interests and survival for the strongest economically, and the ability to plan sound strategically and maintain the positives and elements of economic development and address crises in light of the repercussions and challenges at all levels.

\section{Recommendations:}

- Develop national strategic plans with objectives to achieve economic development.

Supporting scientific research in the field of economics and benefiting from indicators related to economic development.

Directing all the state's economic resources towards industries in a manner equal to investments.

- The executive authorities must be committed to promoting ways of currency stability.

- The necessity of researching economic indicators to reinforce the positives, address economic crises and develop alternative solutions.

\section{References:}

The comprehensive dictionary of meanings.

Abu Amer, Alaa (2004),"International Relations, Diplomacy, Phenomenon, Science, and Strategy", Dar Al-Shorouk for Publishing and Distribution, Amman. 
Al-Tuni ,Muhammad (1996), "Policies of economic and financial reform in the face of the fiscal deficit and structural imbalances in the Kuwaiti economy," the Journal of Finance and Industry.

Al-Qaisi ,Issa (1993), "Population and Employment in the Kuwaiti Economy: Problem and Policies", Scientific Conference of Kuwaiti Economists, "Future Directions of the Kuwaiti Economy".

Al-Tuni, Muhammad (1998), "A Standard Study of the Demand for Labor in Social Work Activity in the State of Kuwait", Wadih.

Wadih, Adnan (2001), "Education and the Labor Market: The Necessities of Reform, a Case Study of Kuwait," the Arab Planning Institute.

Abu Qahaf, Abdul Salam (2002), "International Business Administration", New University House for Publishing and Distribution, Egypt.

Ismail, Muhammad (1992), "The Economics of Industry and Manufacturing", University Youth Foundation, 1st Edition, Alexandria, Egypt.

Abdel Razek, Mahmoud (2006), "Information Technology, Increasing Exports and Supporting Industrial Development," Al-Hurriya Library for Publishing and Distribution, Egypt.

Al-Qasim, Najat, The Economic and Political Development of Kuwait in the InterWar Period", 1914: 1939.

Ghanem, Muhammad (2009), "The Kuwaiti Economy: Parasitism and the Mobi Occupation", the Arab Spread Foundation.

Abu Amer, Alaa (2004), "International Relations, Diplomacy, Phenomenon, Science, Strategy", Dar Al-Shorouk for Publishing and Distribution,.

Jamo, Fayza (2015), "Cultural Obstacles to the Economic Development Project", Transformations of the Agricultural and Industrial Economy, and the Development of Society. 
Academic Journal of Research and Scientific Publishing | Vol 3 | Issue 28

Publication Date: 5-8-2021 ISSN: 2706-6495

Al-Tuni, Mohammed (2002) "Labor and Human Development Policies in the Arab Countries: An Analysis of the Kuwaiti Experience".

\section{Websites:}

Oxiford.3eme edition.London.2004.p87

https://www.cbk.gov.kw/en/monetary-policy/exchange-rate-policy

http://pubcouncil.ku.edu.kw/jgaps/homear.

Copyright (C) 2021 Mariam Ahmed Almutairi, AJRSP. This is an open-access article distributed under the terms of the Creative Commons Attribution License (CC BY NC).

Doi: doi.org/10.52132/Ajrsp.e.2021.283 